\title{
Management of common property land resource in zone IV of Rajasthan
}

G.L. MEENA AND PHOOL CHAND MEENA

\begin{abstract}
The study was conducted during 2014 in Zone IV of Rajasthan. Availability of Common property land resource (CPLR) in Zone IV visa-vis Rajasthan has been assessed by using secondary data on fallow land other than current, cultivable wastes, permanent pastures and grazing lands, barren and uncultivable lands, forest land and human population for the year 2001-02 and 2011-12. The results of the study revealed that the percentage of common property land resource available as total geographical area was higher in zone IV (58.32) than that of Rajasthan (37.50). Around 3 per cent reduction over last decade was observed in common property land among all the districts of zone IV and Rajasthan. Per capita availability of CPLR has also declined from 0.30 to 0.23 hectare and 0.25 to 0.19 hectare in zone IV and Rajasthan, respectively, during the study period. The grazing land as a percentage of geographical area was more than one and half times in Zone IV (8.24) as compared to Rajasthan state (4.94). Overall percentage of grazing land to total geographical area in Rajasthan was negligible decreased over last decade, while reverse trend was observed in the case of Zone IV.
\end{abstract}

KEY WORDS : Common property, Grazing, Forest, Geographical area, Per capita availability

How to cite this paper : Meena, G.L. and Meena, Phool Chand (2015). Management of common property land resource in zone IV of Rajasthan. Internat. J. Com. \& Bus. Manage, $8(1): 70-74$.

\section{MEMBERS OF THE RESEARCH FORUM}

Correspondence to:

G.L. MEENA, Department of Agriculture Economics and Management, Rajasthan College of Agriculture, Maharana Pratap University of Agriculture and Technology, UDAIPUR (RAJASTHAN) INDIA

Email: glm57@ rediffmail.com

\section{Authors' affiliations:}

PHOOL CHAND MEENA, College of Agriculture, Agriculture University, JODHPUR (RAJASTHAN) INDIA

Email: bassi_meena@ rediffmail.com 